University of Nebraska - Lincoln

DigitalCommons@University of Nebraska - Lincoln

Publications, Agencies and Staff of the U.S.

Department of Commerce

U.S. Department of Commerce

2010

\title{
History and fate of a small isolated population of Weddell seals at White Island, Antarctica
}

Thomas S. Gelatt

University of Minnesota, St. Paul

Corey S. Davis

University of Alberta

Ian Stirling

University of Alberta

Donald B. Siniff

University of Minnesota, St. Paul

Curtis Strobeck

University of Alberta

See next page for additional authors

Follow this and additional works at: https://digitalcommons.unl.edu/usdeptcommercepub

Part of the Environmental Sciences Commons

Gelatt, Thomas S.; Davis, Corey S.; Stirling, Ian; Siniff, Donald B.; Strobeck, Curtis; and Delisle, Isabelle, "History and fate of a small isolated population of Weddell seals at White Island, Antarctica" (2010). Publications, Agencies and Staff of the U.S. Department of Commerce. 206.

https://digitalcommons.unl.edu/usdeptcommercepub/206

This Article is brought to you for free and open access by the U.S. Department of Commerce at DigitalCommons@University of Nebraska - Lincoln. It has been accepted for inclusion in Publications, Agencies and Staff of the U.S. Department of Commerce by an authorized administrator of DigitalCommons@University of Nebraska - Lincoln. 


\section{Authors}

Thomas S. Gelatt, Corey S. Davis, Ian Stirling, Donald B. Siniff, Curtis Strobeck, and Isabelle Delisle 


\title{
History and fate of a small isolated population of Weddell seals at White Island, Antarctica
}

\author{
Thomas S. Gelatt · Corey S. Davis · Ian Stirling • \\ Donald B. Siniff · Curtis Strobeck · Isabelle Delisle
}

Received: 20 June 2008/ Accepted: 5 February 2009/Published online: 21 February 2009

(C) Springer Science+Business Media B.V. 2009

This article is a U.S. government work, and is not subject to copyright in the United States.

\begin{abstract}
Weddell seals (Leptonychotes weddellii Lesson) at White Island, Antarctica form a small, completely enclosed, natural population hypothesized to be of recent origin, likely founded by individuals from nearby Erebus Bay. This population constitutes an ideal model to document a founder event and ensuing genetic drift, with implications for conservation. Here we combined historical accounts, census and tagging data since the late 1960s, and genetic data (41 microsatellite loci and mitochondrial DNA sequences) from 84 individuals representing nearly
\end{abstract}

T. S. Gelatt

Department of Fisheries and Wildlife, University of Minnesota,

St. Paul, MN, USA

C. S. Davis · I. Stirling · C. Strobeck

Department of Biological Sciences, University of Alberta,

Edmonton, AB, Canada

I. Stirling

Canadian Wildlife Services, Edmonton, AB, Canada

D. B. Siniff

Department of Ecology, Evolution and Behavior,

University of Minnesota, St. Paul, MN, USA

I. Delisle

Campus Saint-Jean, University of Alberta, Edmonton,

AB, Canada

e-mail: idelisle@ualberta.ca

Present Address:

T. S. Gelatt $(\bowtie)$

National Marine Fisheries Service, Alaska Fisheries Science

Center, National Marine Mammal Lab, 7600 Sandpoint Way

NE, Seattle, WA 98115, USA

e-mail: Tom.Gelatt@noaa.gov all individuals present between 1990 and 2000 to investigate the history of the founding of the White Island population, document its population dynamics and evaluate possible future threats. We fully resolved parental relationships over three overlapping generations. Cytonuclear disequilibrium among the first generation suggested that it comprised the direct descendants of a founding group. We estimated that the White Island population was founded by a small group of individuals that accessed the island during a brief break in the surrounding sea ice in the mid-1950s, consistent with historical accounts. Direct and indirect methods of calculating effective population size were highly congruent and suggested a minimum founding group consisting of three females and two males. The White Island population showed altered reproductive dynamics compared to Erebus Bay, including highly skewed sex ratio, documented inbred mating events, and the oldest known reproducing Weddell seals. A comparison with the putative source population showed that the White Island population has an effective inbreeding coefficient $\left(F_{\mathrm{e}}\right)$ of 0.29 . Based on a pedigree analysis including the hypothesized founding group, $86 \%$ of the individuals for whom parents were known had inbreeding coefficients ranging 0.09-0.31. This high level of inbreeding was correlated with reduced pup survival. Seals at White Island therefore face the combined effects of low genetic variability, lack of immigration, and inbreeding depression. Ultimately, this study provides evidence of the effects of natural isolation on a large, long-lived vertebrate and can provide clues to the potential effects of anthropogenic-caused isolation of similar taxa.

Keywords Founder effect - Genetic drift . Inbreeding depression - Survival - Parentage analysis . Pedigree analysis - Leptonychotes weddellii 


\section{Introduction}

Weddell seals (Leptonychotes weddellii Lesson), found in the fast ice-covered seas around Antarctica (Stirling 1971a), live farther south than any other mammal (Riedman 1990). The southernmost population of Weddell seals is found at White Island, McMurdo Sound, Antarctica $\left(77^{\circ} 10^{\prime} \mathrm{S}, 167^{\circ} 20^{\prime} \mathrm{E}\right.$; Fig. 1$)$, where it is enclosed by the Ross and McMurdo Ice Shelves. The minimum distance between the island and open water averages approximately $20 \mathrm{~km}$, but varies annually depending on the extent of seaice break-out in McMurdo Sound. Except for a narrow crack along the island's northwestern side (Stirling 1966), maintained by tidal action and movement of the ice shelf, the ice exceeds $15 \mathrm{~m}$ thick within $20 \mathrm{~m}$ of shore (Castellini et al. 1984, 1991). There are no other known cracks or holes in the vicinity. A small isolated population of Weddell seals breeds and pups at White Island and uses the tidal crack as its only access to the surface.
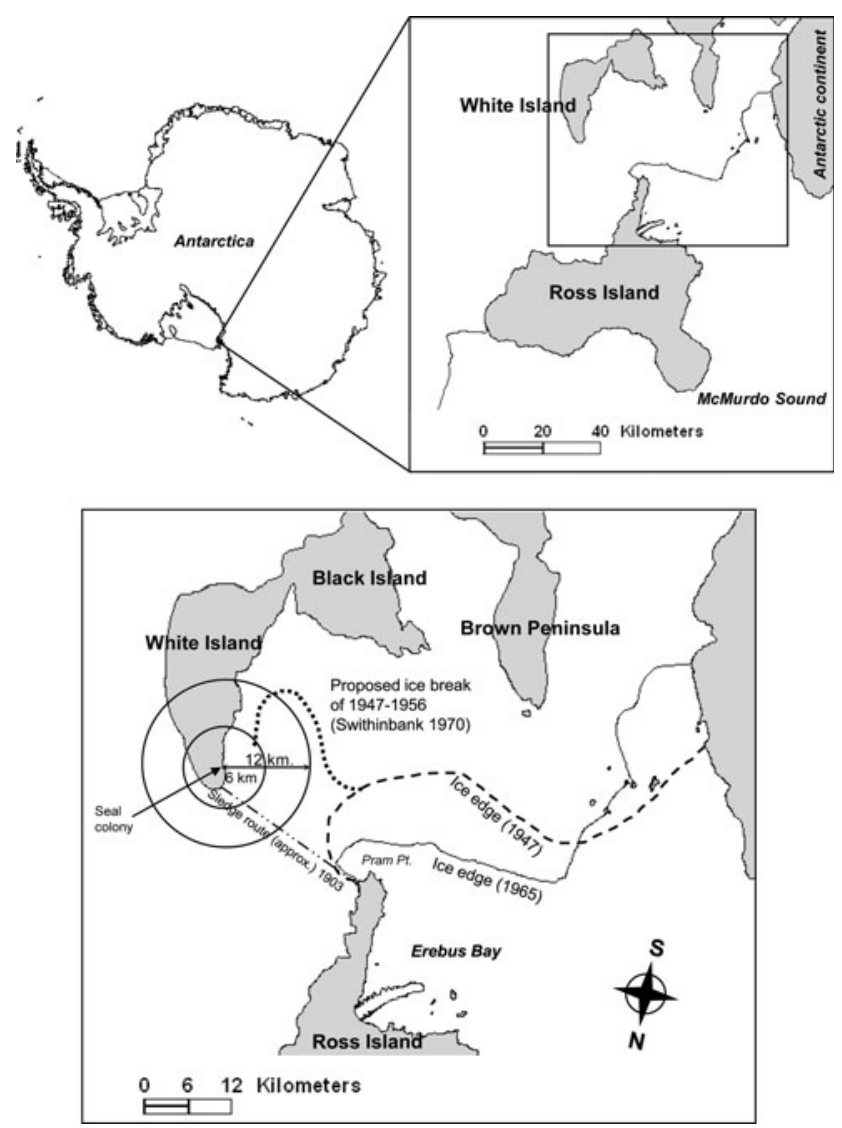

Fig. 1 White Island, McMurdo Sound, Antarctica. The Weddell seal population at White Island can only surface at a tidal crack located at the northern tip of the island. The island population is isolated from its probable source population at Erebus Bay by the extensive ice shelf. The 1965 ice edge is representative of the transition from sea ice to the current ice shelf. Swithinbank (1970) has proposed an ice break event that occurred between 1947 and 1956. This event would have made the passage between Erebus Bay and White Island possible
This population, known since the late 1950s (Heine 1960), is hypothesized to have been founded around that time by migrants from the nearby Erebus Bay (Stirling 1966). Absence of protein differentiation between the White Island and Erebus Bay populations (Shaughnessy 1969), based on samples collected during the 1960s, supports that idea. The ice shelf physically obstructs the passage to open water in Erebus Bay, and therefore the White Island population is thought to have been isolated from other populations ever since the time of its discovery. Stirling (1972) tagged and re-sighted over 9,000 seals in Erebus Bay and White Island between 1966 and 1968, but never recorded any movement between these populations. More recently, since 1990, annual censuses and tagging of thousands of seals in the same populations provided no evidence of migration between them (Testa and Scotton 1999). The population at White Island tripled (up to about 26 seals) between the mid-1960s and 1994, although high pup mortality and low pup production could indicate inbreeding (Testa and Scotton 1999). Collectively, this previous research suggests a recent founder event involving a low effective population number.

Population fragmentation resulting from anthropogenic causes is an important concern for conservation biology. The study of naturally occurring small populations is of interest for the understanding of founding and bottleneck events, differentiation and speciation processes, and, particularly, extinction. Such natural examples make it possible to observe the process without an obligation to interfere (Testa and Scotton 1999). The population of Weddell seals at White Island offers an opportunity to document the evolution of a small, geographically isolated population of large mammals, located at the extreme of its species' range and to observe a recent founder event and its consequences.

The question of whether to prioritize genetic or demographic factors when investigating the risks facing small populations has been debated at length (Caro and Laurenson 1994; Caughley 1994; May 1995; Hedrick et al. 1996; Eldridge et al. 1999). However, it seems apparent that these processes do not act independently (Gilpin and Soule 1986; Nunney and Campbell 1993; Hedrick 1996; Frankham 1997). Simultaneous examination of demographic and genetic structure within small or shrinking populations may reveal information about their status and trajectory that would be unattainable with only one method (Creel 1998). Unlike captive programs where founders are often known and a complete population pedigree can be constructed (Lacy et al. 1995), the individuals present during the founder or bottleneck event in a wild population are rarely available for sampling. In these situations, existing data on the population ecology and biology of the species can refine a genetic analysis by providing the parameters that govern population structure (Packer et al. 1991). 
Such a body of knowledge is available for Weddell seals. In particular, the Erebus Bay population, the probable source of the White Island colony, has been under continual investigation since the late 1960s (Stirling 1969, 1971b, 1972; Siniff et al. 1977; Testa and Siniff 1987; Cameron and Siniff 2004; Hadley et al. 2006; Proffitt et al. 2007). Weddell seals are iteroparous, pupping and breeding annually at traditional colonies between mid-November and mid-December. Pups are weaned approximately 5-6 weeks later and both adults and pups depart separately as the sea ice breaks up. Individuals of both age classes remain in the area or spend the austral winter in the pelagic zone or pack ice (Testa 1994; Stewart et al. 2000). White Island seals give birth approximately 3 weeks later than in Erebus Bay, and the weaned pups are unable to emigrate due to the ice shelf. The complete isolation of the White Island population from its putative source, and the substantial database on individual life histories and behavior made available through their extensive study, provide an ideal system and a strong foundation for interpreting mechanisms acting on population structure.

Our objectives were to investigate the history of the founding of the White Island population, document its current dynamics and evaluate possible future threats. Using historical data, demographic data from census and life-history records, and genotypic data from almost all of the population present between 1990 and 2000, we re-constructed the complete history of the population and examined potential indicators, such as level of inbreeding, of its future.

\section{Methods}

\section{Historical data}

Annual censuses and tagging records were available for Weddell seals in McMurdo Sound dating from the late 1960s. To gain historical information on the White Island population, we surveyed journals, maps, reports and other accounts from exploratory and early travelers in the region, and interviewed biologists and glaciologists who worked in the area. Any mention of seal sighting or trace was recorded. Relevant information about the glaciology of the region at the hypothesized time of founding was also noted.

\section{Tagging and censuses}

Trips from McMurdo to White Island were made 2-4 times a season between late October and mid-February to document and tag Weddell seals. The majority of annual visits occurred during November and December, a period when primarily adult females and pups are observed on the surface. Most male observations occurred in January and February but were less common due to a lower frequency of researcher visits. Seals were marked with cattle ear tags in the rear and front flippers by researchers from the New Zealand Antarctic Program (NZAP), 1968-1978 (Stirling 1972), and by those from the US Antarctic Program (USAP; rear flippers only), 1990-2000. We used field notes, tagging records, and annual censuses taken 19902000 to document annual presence and reproduction over the 1968-2000 period.

We calculated the total adult population of White Island $(N)$ for each census year from 1990 to 2000 using the following assumptions: (1) all seals more than 4 years of age were adult and capable of breeding; (2) any seal estimated as a subadult at first sighting was an adult in the following year; (3) any seal tagged as an adult between 1991 and 1994 (the last census year any untagged adult was seen) was present as a breeding adult since 1991 (these conservative assumptions may erroneously increase the number of individuals available for breeding if some were actually still too young to breed); and (4) any seal not seen within 3 years of its last sighting had died. We supplemented annual counts if a seal was not seen in the census year but was seen in subsequent years or if its presence was revealed by the genetic identity of its offspring the following year (see parentage and pedigree analyses).

We approximated effective population size, $N_{\mathrm{e}}$, by including only those individuals known to have bred successfully in a given year in the biased sex ratio formula $N_{\mathrm{e}}=4 M F / M+F$ where $M$ and $F$ represent total number of males and females, respectively (Lande and Barrowclough 1987; Caughley 1994). The resulting value of $N_{\mathrm{e}}$ is hereafter referred to as $N_{\mathrm{b}}$, the effective number of breeders. The harmonic mean $N_{\mathrm{b}}$ was also calculated for the overall period.

We estimated sex-specific reproductive success for the study period by calculating reproductive rate for each individual based on the sum total of pups sired by or born to a given adult during the years it was known to be present and of breeding age, and averaging over all pups born. We assigned reproductive success to females in the year of the pup's birth and to males in the year of the mating, i.e., 1 year prior to the birth. We estimated generation time $(T)$ from the mean age of reproduction of both sexes pooled (Lande and Barrowclough 1987).

\section{DNA sampling}

Dermal or blood samples were collected from a total of 84 individual Weddell seals over the 1990-2000 period. Genomic DNA was extracted from tissue or isolated white blood cells using QIAamp ${ }^{\mathrm{TM}}$ spin columns (QIAGEN). 


\section{Genotyping}

We genotyped each seal at 41 microsatellite loci: 22 developed from Antarctic monachines by Davis et al. (2002) (excluding their $L w-9$ and $L w-18$ ); two previously unpublished loci developed from the leopard seal, $\mathrm{Hl}-10$ and $\mathrm{Hl}-12$ (Genbank accession numbers EU523152 and EU523153); six other seal loci, $\mathrm{Hg} 3.7, \mathrm{Hg} 6.1, \mathrm{Hg} 6.3, \mathrm{Pv}$ 11 (from Gemmell et al. 1997), $P v c 30$ and $P v c 78$ (from Coltman et al. 1996); and 11 other carnivore loci; $C X X 20$, CXX 110, CXX 123, CXX 213 (from Ostrander et al. 1993), Fca 26, Fca 35, Fca 43, Fca 78 (from Menotti-Raymond and O'Brien 1995), Ma-10 (Davis and Strobeck 1998), G1A (Paetkau and Strobeck 1995) and Lc109 (Carmichael et al. 2000). PCR was performed as previously described in Davis et al. (2002) and PCR products were resolved on a model 373A DNA Sequencer and scored using Genescan and Genotyper software (PE Biosystems).

From the individual genotypes, we calculated individual and mean observed heterozygosity $H_{\mathrm{O}}$, expected heterozygosity $H_{\mathrm{E}}$ (Nei and Roychouddhoury 1974), total number of alleles at each locus, and mean number of alleles across loci.

Tests of Hardy-Weinberg equilibrium for each locus and linkage disequilibrium between each pair of loci were performed using GENEPOP on the web (http://genepop. curtin.edu.au/; Raymond and Rousset 1995). Because of the relatively large number of known parent-offspring relationships at White Island, only genotypes of adults with no known ancestors in the population $(N=18)$ were used in these tests.

\section{Mitochondrial haplotyping}

We sequenced a 619 bp fragment of mitochondrial DNA (mtDNA) consisting of $120 \mathrm{bp}$ of the $3^{\prime}$ end of the cytochrome $b$ gene and $499 \mathrm{bp}$ of the $5^{\prime}$ end of the control region. Chimeric primers consisting of mtDNA specific sequences (Shields and Kocher 1991) and universal sequencing primer sequences (universal forward/L15774: 5'-CGA CGT TGT AAA ACG GCC AG/T ACA TGA ATT GGA GGA CAA CCA GT-3'; universal reverse/ H16498: 5'-GGA AAC AGC TAT GAC CAT TAC G/CC TGA ACT AGG AAC CAG ATG-3') were used to amplify template for sequencing. Approximately $200 \mathrm{ng}$ of DNA were used in $50 \mu \mathrm{l} \mathrm{PCR}$ reactions also containing $0.80 \mu \mathrm{M}$ of each primer, $80 \mu \mathrm{M}$ dNTPs, $2.05 \mathrm{mM} \mathrm{MgCl}_{2}, 3$ units of Taq DNA polymerase and $1 \times$ PCR buffer $(10 \mathrm{mM}$ Tris buffer, $\mathrm{pH} 8.8,0.1 \%$ Triton $\times 100,50 \mathrm{mM} \mathrm{KCl}$ and $0.16 \mathrm{mg} / \mathrm{ml} \mathrm{BSA).} \mathrm{Cycling} \mathrm{was} \mathrm{performed} \mathrm{on} \mathrm{a} \mathrm{Perkin}$ Elmer ${ }^{\mathrm{TM}} 9600$ thermal cycler under the cycling conditions: $94^{\circ} \mathrm{C}$ for $5 \mathrm{~min}$ followed by 35 cycles of $94^{\circ} \mathrm{C}$ for $30 \mathrm{~s}$, $52^{\circ} \mathrm{C}$ for $30 \mathrm{~s}, 72^{\circ} \mathrm{C}$ for $30 \mathrm{~s}$ and a final extension at $72^{\circ} \mathrm{C}$ for $5 \mathrm{~min}$. Amplified product was isolated on $1 \%$ agarose gels, and recovered using QIAquick ${ }^{\mathrm{TM}}$ spin columns (QIAGEN). Sequence was determined using ABI dRhodamine sequencing chemistry with the forward $\left(5^{\prime}\right.$-CGA CGT TGT AAA ACG ACG GCC AG-3') and reverse (5'GGA AAC AGC TAT GAC CAT GAT TAC G) universal sequencing primers and resolved on an ABI 377 DNA sequencer. Sequences were aligned in Sequence Navigator $1.2(\mathrm{ABI})$

Parentage and pedigree analyses

We used the program CERVUS 3.0 (Marshall et al. 1998; Kalinowski et al. 2007) to perform parentage analysis. Because no untagged adults were sighted at White Island after February of 1994, and the population is isolated, we assumed that the entire living adult population had been marked and sampled. We performed parentage analysis for all pups and for those adults which could be inferred to be younger than the rest based on tagging and observational data ( 8 out of 26 , leaving the group deemed the 18 oldest). We performed sequential parentage assignment analyses, each time adjusting the sample files to include only individuals that had reached breeding age into the candidate parent file. We used trio LOD score and a 99\% confidence level for assignment. Maternal assignments were verified against recorded mother-pup pairs at time of tagging. Inferred relationships were built into a pedigree using Pedigraph $^{\mathrm{TM}}$ (Garbe and Da 2006). The pedigree rendition was modified manually to add a time axis for births.

Cytonuclear disequilibrium

Relationships among the 18 oldest individuals were reconstructed in a neighbor-joining tree using PHYLIP 3.572 (Felsenstein 1993), based on a pairwise distance matrix of the proportion of shared alleles $\left(d^{\prime}{ }_{i j}=1-P_{i j}\right.$; where $P_{i j}$ is the fraction of shared alleles between individuals $i$ and $j$ ) after Bowcock et al. (1994) and implemented at http://www2.biology.ualberta.ca/jbrzusto/ sharedst.php. Nodal bootstrap support values were obtained from 100 pseudo-replicates generated by re-sampling the dataset over loci. Mitochondrial haplotypes were mapped onto the resulting nuclear tree to visualize cytonuclear disequilibrium, i.e., the non-random association of mitochondrial haplotypes and nuclear alleles. We expected that if the population had been recently founded by a small number of individuals, the tree would show groups of individuals sharing haplotypes, indicating apparent nonrandom mating caused by a short time since founding. The probability of obtaining the observed disequilibrium by chance in a random mating population was evaluated by simulating 100 comparable datasets of 18 individuals 
genotypes drawn at random from the observed allelic frequencies. For each dataset, we generated the allele sharing tree, mapped haplotypes, and computed consistency index (Kluge and Farris 1969). We determined significance level by comparing the observed consistency index value to its simulated distribution.

\section{Founding history}

To get a complete picture of the population's founding history, we combined and compared different approaches.

We inferred the number of generations since founding $(t)$ based on the hierarchy of relationships in the pedigree analysis. With cytonuclear disequilibrium suggesting that the oldest individuals are the direct descendants of the founders, we added a single generation $\left(G_{0}\right)$ to the pedigree total.

We estimated the time since founding by multiplying $t$ by the generation time $(T)$. Independent timing estimates were obtained from historical observations.

Information about the number of founders was obtained by combining (1) historical data, (2) an analysis based on inheritance principles of the nuclear and mitochondrial genotypes of the 18 oldest individuals, and (3) two different methods of calculating $N_{\mathrm{e}}$ from genetic data: one from Pudovkin et al. (1996) based on heterozygote-excess and implemented in the program NeEstimator (Peel et al. 2004) and the other based on linkage disequilibrium following Waples (2006) and implemented in the program LDNe (Waples and Do 2008). We also used the genetic drift formula to estimate the number of founders $N_{\mathrm{f}}=$ $1 / 2\left(1-e^{\left[\ln \left(H_{\mathrm{t}} / H_{0}\right)\right] / t}\right)$ following Hedrick (after Hedrick et al. 2001, 2005), with $H_{0}$ corresponding to heterozygosity of the source population in Erebus Bay and $H_{\mathrm{t}}$ to that of a given generation at White Island.

Using the pedigree analysis, we inferred the number of breeders on years of sampling. These "true" $N_{\mathrm{b}}$ values based on breeding data were compared to $N_{\mathrm{e}}$ values calculated using the two methods described above. For populations with overlapping generations, as is the case in Weddell seals, these approaches have actually been suggested to estimate $N_{\mathrm{b}}$ rather than $N_{\mathrm{e}}$ (Waples and Yokota 2007).

\section{Inbreeding}

We calculated the effective inbreeding coefficient $\left(F_{\mathrm{e}}\right)$ using the equation $F_{\mathrm{e}}=1-H_{\mathrm{IS}} / H_{\mathrm{M}}$ (Frankham 1998), with $H_{\mathrm{M}}$ as the heterozygosity of Erebus Bay and $H_{\mathrm{IS}}$ that currently found in the White Island population.

We calculated individual inbreeding coefficients from the pedigree using the program Pedigraph ${ }^{\mathrm{TM}}$ (Garbe and Da 2006). We also performed the same calculation using the assumptions of our founding history reconstruction. We then compared the inbreeding coefficients of surviving (i.e., re-sighted at least once since birth) versus nonsurviving pups born 1990-1997 using a Wilcoxon-MannWhitney test. We chose to exclude pups born after 1997 from the analysis to allow sufficient time for re-sighting younger individuals as subadults or adults. Finally, we calculated the projected inbreeding coefficients of future offspring of the surviving pups.

\section{Results}

\section{History}

The first historical accounts of White Island were the field journals from R. F. Scott's three British Antarctic Expeditions (1902, 1903, and 1910). Most significantly, a small party led by naturalist Edward Wilson failed to note any seals at White Island despite circling the island by foot and climbing to its summit in February 1902 (Armitage 1905; Wilson 1907; Worsley 1931; Seaver 1933). Maps of the sledge routes followed by subsequent parties through 1910 indicated that the primary location of the modern-day White Island seal population was passed numerous times (e.g., Armitage 1905; Fig. 1). There was no mention in Wilson's notes or any of the expedition journals of the presence of seals or seal sign at White Island during this time.

Infrequent human presence in the region between the British Antarctic Expedition of 1910-1911 and 1957-1958 when McMurdo Station was constructed, provided limited information of the local glaciology. From 1958 on, there was good documentation of the annual extent of the ice shelves (MacDonald and Hatherton 1961; Heine 1963; Stuart and Bull 1963; Prebble 1967; Swithinbank 1970). A line delineating the 1947 ice edge on US Navy Hydrographic Office chart 6666 (1st Ed. 1956) represented the most extensive break-out recorded (Fig. 1). However, in 1970, Swithinbank speculated that a line traced on a 1956 aerial photograph "...might represent the line of an ice break-out that occurred sometime between 1947 and 1956" (Swithinbank 1970; Fig. 1).

The first noted observation of seals at White Island was by glaciologist A. Heine. He first recorded Weddell seals at White Island in 1958-1959, noting "two live seals lying among the pressure ridges around the north-eastern end" (1960). Likewise, New Zealand researcher G. Caughley reported that "three seals were seen beside a tide crack at White Island" on December 30, 1958 (Caughley 1959). The next record was from 1961, when W. H. Deverall noted 11 seals of unknown age (Unpublished US Navy report). Field notes, letters, and incidental literature indicated 3-11 seals present and reproducing at White Island since at least 1964 (Table 1). 
Table 1 Sightings and anecdotal reports of Weddell seals at White Island from 1958 to 1981

\begin{tabular}{|c|c|c|c|c|c|c|c|c|c|c|c|c|}
\hline \multirow[t]{2}{*}{ Source } & \multirow[t]{2}{*}{ Date } & \multirow{2}{*}{$\begin{array}{l}\text { Unknown } \\
\text { age class }\end{array}$} & \multicolumn{3}{|c|}{ Adult } & \multicolumn{2}{|c|}{ Subadult } & \multicolumn{3}{|c|}{ Pup } & \multirow{2}{*}{$\begin{array}{l}\text { Dead } \\
\text { pup }\end{array}$} & \multirow[t]{2}{*}{ Comments } \\
\hline & & & $?$ & $\hat{\sigma}$ & q & $? \hat{0}$ & 우 & $?$ & $\hat{o}$ & q & & \\
\hline Heine (1960) & 1958-1959 & & 2 & & & & & & & & & \\
\hline G. Caughley & December 1958 & 3 & & & & & & & & & & \\
\hline Deverall $(1961)^{\mathrm{a}}$ & January 1961 & 11 & & & & & & & & & & Aerial survey only \\
\hline Littlepage $(1966)^{\mathrm{b}}$ & 1961-1962 & & 2 & & & & & 1 & & & & $\begin{array}{l}\text { Aerial survey only. "These seals were seen every } \\
\text { time we visited the Island from November } \\
1961 \text { to January } 1962 \text { at the north end" }\end{array}$ \\
\hline Kooyman $(1968)^{\mathrm{c}}$ & December 1964 & & & & 3 & & & 1 & & 1 & 1 & $\begin{array}{l}\text { All seals were together at the eastern tip of the } \\
\text { Island }\end{array}$ \\
\hline \multirow[t]{2}{*}{ Stirling (1972) } & 1965-1966 & & & 1 & $2^{\mathrm{d}}$ & $2^{\mathrm{e}}$ & & 1 & & & & $\begin{array}{l}\text { Stirling notes that he tagged five more seals in } \\
\text { addition to those tagged by Kooyman in } 1964\end{array}$ \\
\hline & 1966-1967 & & & & $2^{\mathrm{f}}$ & & & & 2 & 1 & & $\begin{array}{l}\text { Includes those seen in 1965-1966 and one new } \\
\text { adult female }\end{array}$ \\
\hline Dayton $(1969)^{\mathrm{g}}$ & November 1968 & & 2 & & & & & 2 & & & & $\begin{array}{l}\text { The mother was unusually fat and healthy for } \\
\text { that time of year }\end{array}$ \\
\hline Hughes $(1969)^{\mathrm{h}}$ & February 1969 & & 2 & 1 & & & & & 1 & & & All near NW tip of island \\
\hline \multirow[t]{2}{*}{$\operatorname{Knox}(1979)^{\mathrm{i}}$} & 1976-1977 & & & 4 & 6 & 1 & 3 & 1 & 2 & 1 & & $\begin{array}{l}\text { Knox had a camp at White Island between } 15 \\
\text { October } 1976 \text { and } 1 \text { February } 1977 \text { and } \\
\text { surveys were conducted weekly }\end{array}$ \\
\hline & 1978-1979 & & & 4 & 8 & 3 & 1 & & 2 & 1 & 1 & $\begin{array}{l}\text { The only seals not already tagged were the pups } \\
\text { and four subadults (two of which were } \\
\text { yearlings). Knox had a crew camped at the } \\
\text { island between } 4 \text { November } 1978 \text { and } 24 \\
\text { January } 1979\end{array}$ \\
\hline Castellini $(1978)^{\mathrm{j}}$ & December 1978 & & & 1 & 5 & & & 7 & & & & $\begin{array}{l}\text { Pup sexes not noted. All but two pups were } \\
\text { already tagged }\end{array}$ \\
\hline \multirow[t]{2}{*}{ Knox $(1979)^{\mathrm{i}}$} & January 1980 & & & 1 & 1 & 1 & & & 1 & & & $\begin{array}{l}\text { Seven seals were observed from the air but only } \\
\text { five were observed on the ice }\end{array}$ \\
\hline & 1981 & & & 2 & 4 & & & 1 & & & 1 & \\
\hline Castellini (1978) & 1981 & & & 4 & 8 & & & 2 & & & 1 & $\begin{array}{l}\text { "Many" of the adults had fore-flipper tags put } \\
\text { out by NZAP in mid-1970's }\end{array}$ \\
\hline
\end{tabular}

No counts were reported for 1981-1989

${ }^{a}$ Reconnaissance to observe seal population, White Island, 24 January 1961, Memo by Scott base radio officer

b Letter to I. Stirling dated 14 April 1966 noting observations from helicopter flights between November 1961 and January 1962

${ }^{c}$ Letter to I. Stirling dated 8 April 1968 noting observations of 16 December 1964. J. Kooyman first tagged seals at White Island by tagging all five individuals in 1964

${ }^{\mathrm{d}}$ Includes one of the adult females tagged by Kooyman and one untagged

e Both seals were untagged when seen

${ }^{\mathrm{f}}$ Includes one seal tagged previously and one untagged

g Letter to I. Stirling written 26 September 1969

${ }^{\text {h }}$ Letter to I. Stirling dated 4 April 1969 detailing sightings from February of 1969

${ }^{\mathrm{i}}$ University of Canterbury Antarctic Research Unit. Expedition 17G. Knox was the leader of the University of Canterbury team working under the New Zealand Antarctic Program (NZAP)

${ }^{\mathrm{j}}$ Field notes

\section{Demographic data}

Ninety-three individual seals were marked and identified at White Island between 1990 and 2000: 9 males and 14 females were first tagged as adults, one male and two females as yearlings or subadults, 21 males and 43 females as pups, and three more pups were tagged but not sexed. During the survey period, one male and six females attained breeding age. Over the same period, two adult males and three adult females disappeared and were 
presumed dead. Of all the pups tagged, only seven (one male and six females) had been observed in a year other than their birth year as of 2000 .

Mean population size was 25.91 breeding-age adults/ year ( $\mathrm{SD}=0.83$; range 25-27 between 1990 and 2000). Annual totals, sex-specific totals, corresponding $N_{\mathrm{b}}$ and average values are compiled in Table 2 .

Genetic diversity

A total of 84 seals were genotyped. Overall, the White Island population had average observed and expected heterozygosities of 0.56 and 0.53 , respectively, with an average allelic diversity of 3.61 alleles/locus (range 2-6; Table 3).

Based on tagging information and parentage analysis, a set of 18 adults were identified as the oldest individuals of the population, while the other individuals formed two additional generational groups (Generations $G_{1}, G_{2}$ and $G_{3}$; see Fig. 2). Genetic diversity values for these subsets of the population are summarized in Table 3. For comparison purposes, Table 3 also contains diversity data from the Erebus Bay population (based on 17 loci, Gelatt 2001) and corresponding values from the White Island population using the same 17 loci. The White Island population retained $78 \%$ of the observed heterozygosity and $32 \%$ of the allelic diversity of its likely source population.
Table 3 Genetic diversity data

\begin{tabular}{llllll}
41 loci & & & \multicolumn{1}{l}{17 loci $^{\text {a }}$} & \\
\cline { 5 - 6 }$n n$ & $H_{\mathrm{E}}$ & $\begin{array}{l}\text { No. of } \\
\text { alleles }\end{array}$ & $H_{\mathrm{O}}$ & $H_{\mathrm{E}}$ & $\begin{array}{l}\text { No. of } \\
\text { alleles }\end{array}$
\end{tabular}

Overall populations

White Island $(N=84) \quad 0.56 \quad 0.53 \quad 3.61 \quad 0.57 \quad 0.52 \quad 3.82$

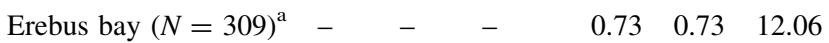

White Island generations

$\begin{array}{lllllll}G_{1}(N=18) & 0.63 & 0.54 & 3.61 & 0.64 & 0.55 & 3.82 \\ G_{2}(N=41) & 0.53 & 0.50 & - & 0.54 & 0.51 & - \\ G_{3}(N=25) & 0.54 & 0.51 & - & 0.55 & 0.51 & -\end{array}$

${ }^{\mathrm{a}}$ Gelatt (2001)

When specifically testing for a deficiency of heterozygotes, no deviation from Hardy-Weinberg equilibrium was detected at any of the 41 loci typed $(P<0.05)$. However, five loci displayed heterozygote excess $(P<0.05)$, although none of these tests remained significant following a strict Bonferroni correction. A global test over all loci also indicated an excess of heterozygotes $(P<0.00001)$. Of 820 pairwise tests of linkage disequilibrium, 120 pairs were significant at $P<0.05$. Only three of these tests remained significant following a strict Bonferroni correction.

Three mitochondrial haplotypes were found among the 18 oldest individuals of the population (Haplotypes A;

Table 2 Demographics of Weddell seal population at White Island, 1990-2000, based on census and breeding analysis

\begin{tabular}{|c|c|c|c|c|c|c|c|c|c|c|c|c|}
\hline Year of sampling & 1990 & 1991 & 1992 & 1993 & 1994 & 1995 & 1996 & 1997 & 1998 & 1999 & 2000 & Average \\
\hline Females observed during census & 9 & 8 & 13 & 12 & 10 & 9 & 10 & 17 & 16 & 12 & 11 & 11.55 \\
\hline Females assumed present & 5 & 6 & 1 & 3 & 6 & 6 & 8 & 0 & 1 & 5 & 6 & \\
\hline All breeding age females present & 14 & 14 & 14 & 15 & 16 & 15 & 18 & 17 & 17 & 17 & 17 & 15.82 \\
\hline Males observed during census & 5 & 2 & 8 & 10 & 0 & 0 & 2 & 3 & 2 & 6 & 1 & 3.55 \\
\hline Males assumed present & 6 & 9 & 3 & 1 & 10 & 10 & 7 & 6 & 7 & 4 & 9 & \\
\hline All breeding age males present & 11 & 11 & 11 & 11 & 10 & 10 & 9 & 9 & 9 & 10 & 10 & 10.09 \\
\hline Total $\mathrm{N}$ [breeding age $(>4)$ adults] & 25 & 25 & 25 & 26 & 26 & 25 & 27 & 26 & 26 & 27 & 27 & 25.91 \\
\hline Pup Births (pups sampled) ${ }^{\mathrm{a}}$ & 1 & 6 & 6 & 4 & 5 & 5 & 8 & 7 & 9 & 6 & 10 & 6.60 \\
\hline Maximum number of breeding females & 6 & 6 & 4 & 5 & 5 & 8 & 6 & 9 & 6 & 10 & & 6.50 \\
\hline Minimum number of breeding females & 5 & 5 & 4 & 5 & 5 & 8 & 6 & 9 & 6 & 10 & & 6.30 \\
\hline Maximum number of breeding males & 6 & 3 & 3 & 2 & 4 & 5 & 4 & 6 & 5 & 4 & & 4.20 \\
\hline Minimum number of breeding males & 2 & 2 & 2 & 2 & 2 & 4 & 4 & 6 & 5 & 4 & & 3.30 \\
\hline Maximum total successful breeders & 12 & 9 & 7 & 7 & 9 & 13 & 10 & 15 & 11 & 14 & & 10.70 \\
\hline Minimum total successful breeders & 7 & 7 & 6 & 7 & 7 & 12 & 10 & 15 & 11 & 14 & & 9.60 \\
\hline Maximum $N_{\mathrm{e}}$ for breeders $\left(N_{\mathrm{b}}\right)$ & 12.00 & 8.00 & 6.86 & 5.71 & 8.89 & 12.31 & 9.60 & 14.40 & 10.91 & 11.43 & & 10.01 \\
\hline Minimum $N_{\mathrm{e}}$ for breeders $\left(N_{\mathrm{b}}\right)$ & 5.71 & 5.71 & 5.33 & 5.71 & 5.71 & 10.67 & 9.60 & 14.40 & 10.91 & 11.43 & & 8.52 \\
\hline Maximum $N_{\mathrm{b}} / N$ & 0.48 & 0.32 & 0.27 & 0.22 & 0.34 & 0.49 & 0.36 & 0.55 & 0.42 & 0.42 & & 0.39 \\
\hline Minimum $N_{\mathrm{b}} / N$ & 0.23 & 0.23 & 0.21 & 0.22 & 0.22 & 0.43 & 0.36 & 0.55 & 0.42 & 0.42 & & 0.33 \\
\hline Maximum harmonic mean of $N_{\mathrm{b}}$ & & & & & & & & & & & & 9.30 \\
\hline Minimum harmonic mean of $N_{\mathrm{b}}$ & & & & & & & & & & & & 7.50 \\
\hline
\end{tabular}

a Year 1990 births were not used for calculating the average, as sampling was done too late in the season 
EU523154, B; EU523155 and C; EU523156). The three haplotypes did not group as a clade in a phylogenetic analysis including homologous sequences sampled from Erebus Bay, and are therefore more likely to represent a random sample from the source population rather than to have arisen through mutation from a White Island stock (data not shown).

Parentage and pedigree analysis

Of the 84 seals genotyped, 58 were sampled as pups and 26 at later life stages, mostly adults. We performed parentage analysis on all pups and on eight adults which could be inferred to be younger than the rest based on tagging data. The 18 remaining adults made up the group deemed the 18 oldest ( $G_{1}$ on Fig. 2). For each of the individuals analyzed, a single parent-pair was found and assigned at a $99 \%$ confidence level. A majority of assignments (57 out of 66) had 0 mismatches, and the other nine cases each had a single mismatch. In all cases except one, the second best parent pair had a higher number of mismatches than the assigned pair. In the case of female pup 19, female 22 and male 36 were the best parent pair with 0 mismatches. The second best pair was again female 22 but with male 7 , also with 0 mismatches. This was not surprising since male 36 is the son of male 7. Before accepting the CERVUS assignment result in this case, we further genotyped these four individuals at two X-linked loci ( $L w$-18; Davis et al. 2002 and Pv 17; Gemmell et al. 1997). Paternal alleles being necessarily transmitted to the female progeny, we were able to determine that 7 is the true father as 36 could not have contributed the paternal allele at either X-linked locus.

Nine other pups were tagged but not sampled. Seven of these were with a female when first tagged and assumed to

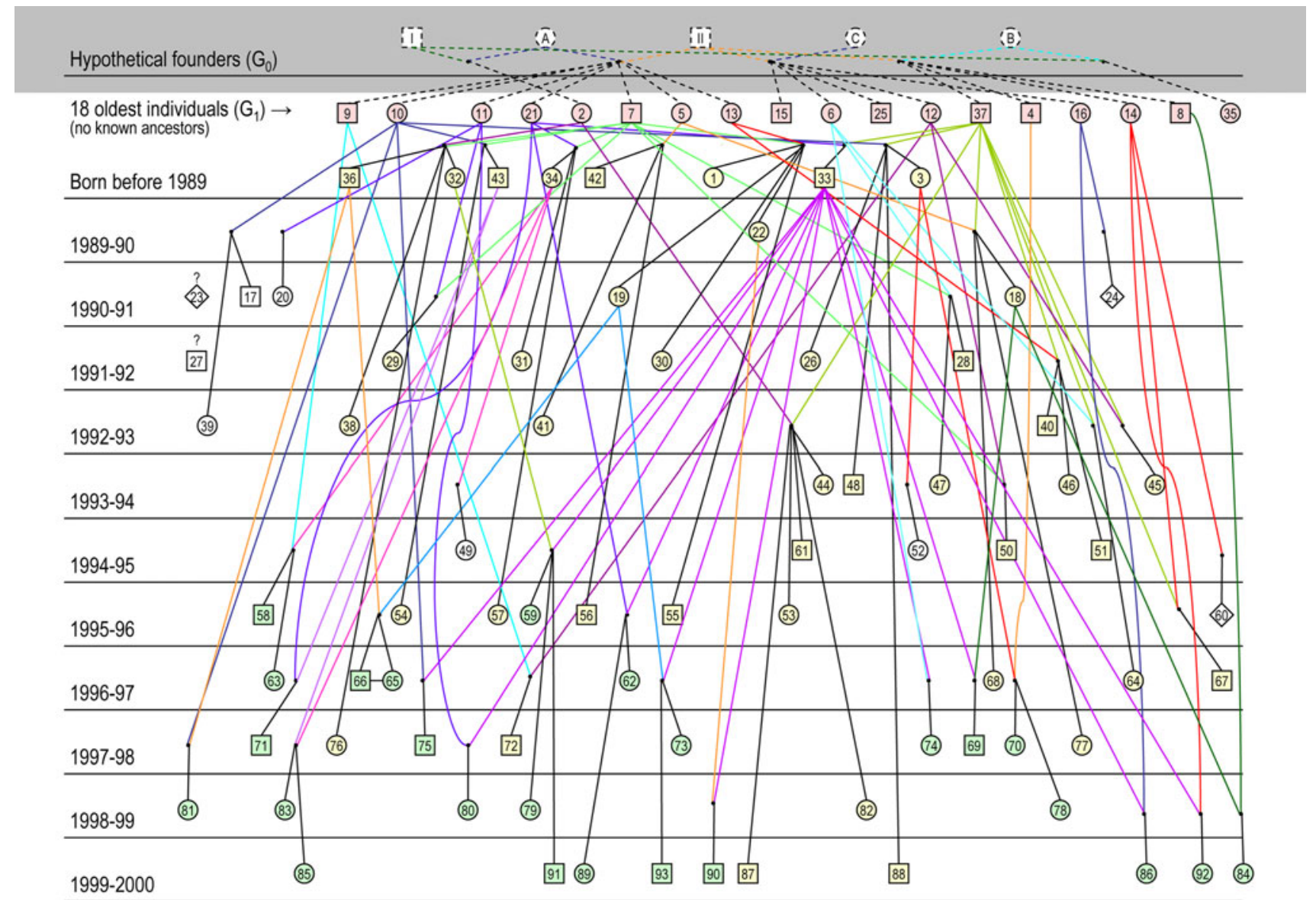

Fig. 2 Pedigree of relationships among Weddell seals sampled and tagged at White Island. The program Pedigraph ${ }^{\mathrm{TM}}$ (Garbe and Da 2006) was used for this reconstruction. The program output comprised three generations, represented here using three colors, pink $\left(G_{1}, 18\right.$ oldest individuals), yellow $\left(G_{2}\right)$ and green $\left(G_{3}\right)$. Pups not genotyped are shown in white symbols. Numbers inscribed in the symbols are truncated individual ID numbers. Colored lines are used to show all matings of a given breeder. Small black dots indicate matings between a parent-pair, on the year of their first known mating. Black lines link progeny to their parent-pair. A time axis was added manually to show individuals on their birth years and to highlight the overlap in generations. Based on our founding model inferences, we postulated three founding females $(A, B$ and $C$ based on mitochondrial haplotypes) and two founding males ( $I$ and $I I$ ); these founders $\left(G_{0}\right)$ were added to the pedigree and are shown in dotted lines within the shaded area 
be a mother-pup pair. Samples were unavailable from the remaining two and their mothers were unknown.

The reconstructed pedigree of the inferred relationships is shown in Fig. 2.

\section{Reproductive success and pup survival}

Twenty adult females were present at White Island over 1990-2000; 17 of them reproduced at least once. If unsampled pups were each born to a different female, a maximum of 19 females would have produced all of the pups. Females gave birth to 0-8 pups over the $1990-2000$ period for a mean reproductive rate of 0.3340 ( $\sigma=0.0616)$. Twelve adult males were sampled during the study period and eight sired 1-17 pups with a maximum of six in 1 year and an average reproductive rate of 0.4394 $(\sigma=0.3469)$. The high variance is explained by the fact that three males (Nos. 7, 33 and 37) sired 79\% of the pups (see Fig. 2).

Seals tagged as adults but without old tags or tag scars were assumed to have birth dates 6 years prior to the time of tagging or known presence based on confirmed parentage. Two males and six females carried tags or tag scars in their front flippers indicating that they had been tagged as pups during 1969-1978 (NZAP) and were conservatively assumed to have birth dates of 1978. Two of these females gave birth in 2000 . Therefore, these females, aged at least 22 , represent a lower-bound estimate of maximum age of reproduction at White Island. Male No. 8 was last seen in 1993 with a NZAP tag but was assigned the paternity of a pup born in 2000, indicating he was present and breeding in 1999 at a minimum age of 21 , making him the oldest known reproducing male Weddell seal. Three of the four known age females recruited to the population gave birth at ages 6,7 , and 10. Based on minimum age estimates, we estimated minimum generation time to be 12.6 years.

On average 6.09 pups were born each year between 1991 and 2000 (range 1-10; Table 2; Fig. 2). Every year except 1995, the sex ratio of pups was either skewed towards females or at equilibrium. The pooled ratio across years, omitting the three pups for whom no sex was available, revealed over twice as many females as males
Fig. 3 Cytonuclear disequilibrium among $G_{1}$ individuals. The neighborjoining tree was constructed on proportion of shared alleles distance $\left(d^{\prime} i j=1-P_{i j}\right.$; where $P_{i j}$ is the fraction of shared alleles between individuals $i$ and $j$ ). Numbers at branch terminal nodes are individual ID numbers. Nodal bootstrap support values were obtained from 100 pseudo-replicates generated by re-sampling the dataset over nuclear loci. Mitochondrial haplotype clusters are shown in boxes. The probability of obtaining the observed disequilibrium by chance was $<1 \%$

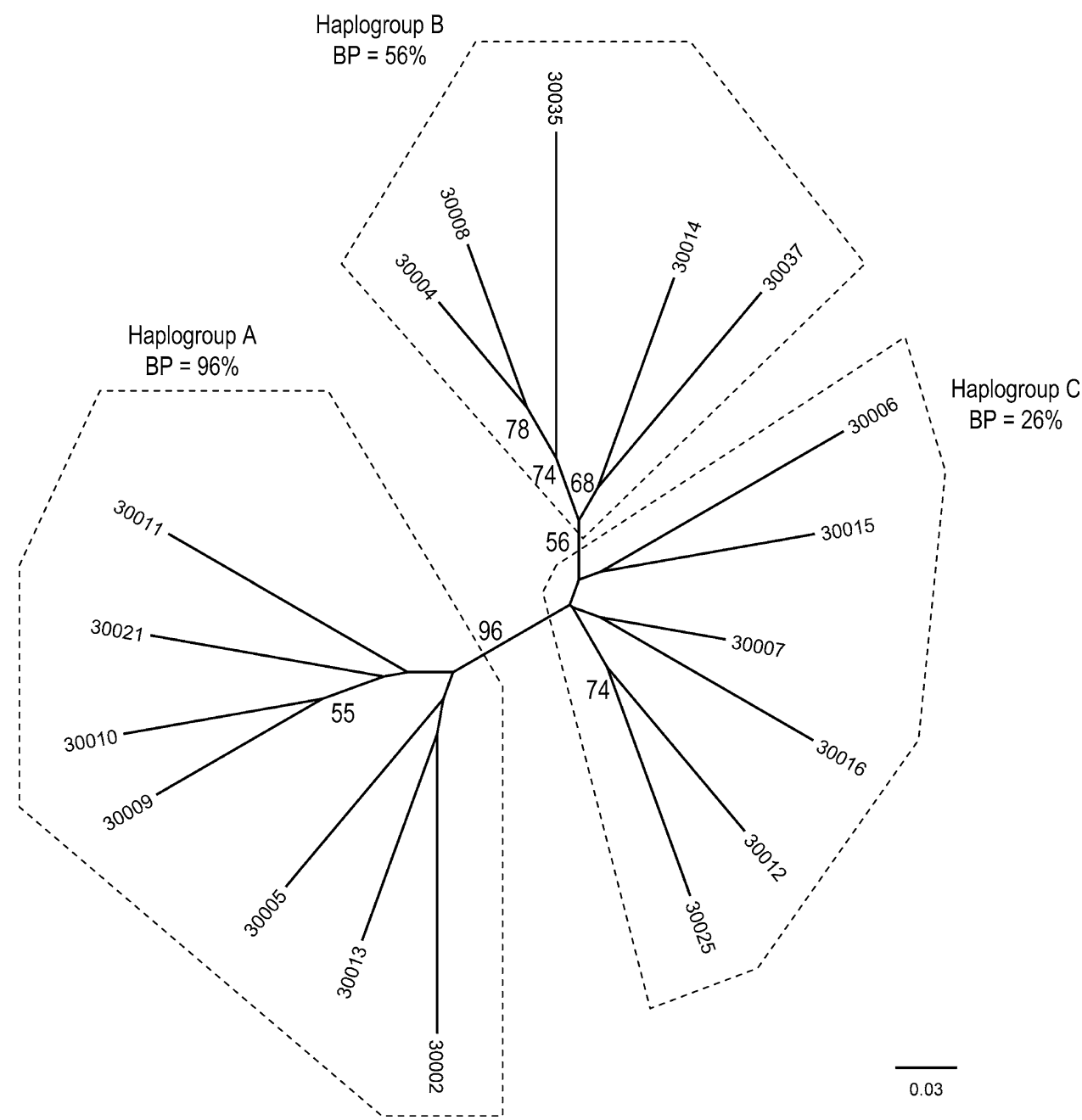


(20 m:45f). Ten (16\%) pups younger than weaning age were found dead. Seven pups (1 m:6f) were seen again in years subsequent to their birth year, for a minimum estimated pup survivorship from birth to the first year of $10.4 \%$. Male No. 37 sired five of these seven survivors and Male No. 7 sired the other two. Conversely, four of the five dead pups for which samples were taken and paternity was assigned were sired by No. 7 .

\section{Cytonuclear disequilibrium}

We hypothesized that if the 18 oldest individuals sampled for which no parents could be found were the direct descendants of the population's founders, they would be in cytonuclear disequilibrium. To verify this prediction, we constructed a neighbor-joining tree based on the proportion of alleles shared (Fig. 3). Individuals' mitochondrial haplotypes were mapped onto the tree and revealed almost complete linkage disequilibrium. Bootstrap support for clustering individuals with the same haplotype was 96 and $56 \%$ for haplotypes A and B respectively, while individuals with haplotype $\mathrm{C}$ did not group as tightly (26\%). Based on the consistency index of simulated data sets, the probability of this distribution pattern occurring by chance in a randomly mating population was less than $1 \%$.

\section{Founder model}

Based on the pedigree analysis, individuals sampled could be grouped into three generations (Fig. 2). The cytonuclear disequilibrium displayed by the 18 individuals with no known parents $\left(G_{1}\right)$ suggested that they were the direct descendants of a founding group, bringing the total time span since founding to four generational groups.

Table 4 Effective number of breeders per generation

\begin{tabular}{llll}
\hline Method & Founders $\left(G_{0}\right)$ & $G_{1}$ & $G_{2}$ \\
\hline Inheritance principles & $5(3 \not 2 \delta$; Ne: 4.8$)$ & - & - \\
Parentage analysis & - & $5.71-$ & $9.60-$ \\
& & $14.40^{\mathrm{a}}$ & $14.4^{\mathrm{b}}$ \\
Heterozygote excess $^{\mathrm{c}}$ & 4.4 & 9 & 11.7 \\
Linkage $_{\quad \text { disequilibrium }}{ }^{\mathrm{d}}$ & $6.1-8.4$ & $12.8-16.3$ & $9.9-13.6$ \\
Genetic drift $^{\mathrm{e}}$ & $3.8-5.8$ & - & - \\
\hline
\end{tabular}

a Table 2 (1990-99)

b Table 2 (1995-1999)

c Following Pudovkin et al. (1996) and implemented in the program NeEstimator (Peel et al. 2004)

${ }^{d}$ Based on Waples (2006) and implemented in the program LDNe (Waples and Do 2008)

e Using $N_{\mathrm{f}}=1 / 2\left(1-e^{\left[\ln \left(H_{\mathrm{t}} / H_{0}\right)\right] / t}\right)$
Using a minimum generation time estimated at 12.6 years, founding could have occurred $1950-1957$. This interval was obtained by regressing four generations from the last year of sampling (2000), or three generations from the year of the first birth of generation $G_{3}$ (1995). The estimate of 1950-1957 is consistent with the timing of the break-out of the ice shelf proposed by Swithinbank (1970) to have occurred between 1947 and 1956. The observations by Heine (1960) and Caughley (1959) of two and three seals, respectively at White Island in 1958 (Table 1) set an upper limit to the time of founding.

Heine's account also represented a minimum for the potential number of founders, as he would have had no way to know if there were additional animals in the water. However, the number of alleles/locus (1-6) implied that, barring mutation, a minimum of three founders was required to account for the allelic diversity found in the population. In turn, the presence of three mitochondrial haplotypes implied a minimum of three females. Assuming three founding mothers, an analysis based on Mendelian principles of inheritance showed that it was logically possible that the entire first generation $\left(G_{1}\right)$, except individuals 2 and 35, shared the same two paternal alleles at all loci and were therefore likely sired by the same male. Whether Nos. 2 and 35 were fathered by one or two different males did not influence our inferences because 35 was never shown to have reproduced. Therefore, a minimum of three females and two males $\left(N_{\mathrm{e}}=4.8\right.$; Table 4$)$ could account for the genetic diversity and genotype patterns found in the population. We obtained a founding $N_{\mathrm{e}}$ value of $4.4 \mathrm{using}$ the heterozygote-excess method and 6.1-8.4 with the linkage disequilibrium approach. We used the same approaches to calculate the number of breeders for each generation (Table 4).

Inbreeding

When compared to Erebus Bay, the inbreeding coefficient $F_{\mathrm{e}}$ at White Island (following Frankham 1998) was 0.29. Based on the parentage and pedigree analyses, seven individuals were known inbreds, with coefficients ranging from 0.125 to 0.25 . The two individuals with an inbreeding value of 0.25 were both female pups sired by the same mother-son pair. Individuals with inbreeding coefficient 0.125 were produced by three different half-sibling dyads, including one that had a set of dyzygotic twins (Gelatt et al. 2001).

By applying our founding model and factoring in the hypothetical founders in the inbreeding coefficient calculations, the number of inbred individuals reached 57, with values ranging from 0.09375 to 0.3125 . Out of 33 pups born between 1990 and 1996, only seven were re-sighted. Survivors had a mean inbreeding coefficient of 0.0714 (SD 
0.0668) while the non-survivors (those that were never re-sighted) had a mean of 0.1407 (SD 0.0826). Using the Wilcoxon-Mann-Whitney test, survivors had significantly lower inbreeding values than non-survivors (one-tailed $P=0.027$ ).

We also calculated that if the surviving pups (one male and six females) went on to reproduce, their offspring would have inbreeding coefficients of 0.0938-0.2500 (average: 0.1615 ). These predicted inbreeding coefficients would reach values typical of non surviving pups.

\section{Discussion}

The White Island population is not unique among Weddell seals. There are reports of other Weddell seal colonies isolated by ice sheets in other areas located at the extremes of the species' range. One such colony comprised of 200 300 individuals was observed multiple times between 1957 and 1963 in rifts in the Ross Ice Shelf near Roosevelt Island but had disappeared when visited again in 2000 (Phil Smith, personal communication). Another population persists in the Bunger Hills (Harry Burton, personal communication). In addition to geographical isolation, there is also evidence of strong behavioral isolation in a colony located in Long Fjord (Davis et al. 2008). While population size is certainly a factor influencing the persistence of such populations, their complete isolation renders them vulnerable to changes in the environment, for instance the closing of the leads in the ice. The extensive amount of data available about the White Island population provides us with an opportunity to better understand the origin and fate of such Weddell seal colonies, and, by extension, of other small and isolated population of large mammals.

\section{Population founder event}

Cytonuclear disequilibrium (Fig. 3) observed among the 18 individuals sampled and genotyped for which no parents could be found $\left(G_{1}\right)$ provides strong evidence that this group represents a first generation after founding. Likewise, significant heterozygote excess and linkage disequilibrium indicate a recent origin. A founding group comprised of three females and two males would have been sufficient to generate the observed genetic diversity and genotypes (nuclear and mitochondrial) among $G_{1}$. Albeit less likely here, cytonuclear disequilibrium may also be caused by population substructure due to assortative mating. This alternative hypothesis would result in the disequilibrium being maintained across generations. Neighbor-joining trees (not shown) of individuals from generations $G_{2}$ and $G_{3}$ revealed no disequilibrium.
The Weddell seal population at White Island is therefore of recent origin, but is currently isolated from the closest and likely source population in Erebus Bay (Fig. 1). Three possible scenarios may be considered for the initiation of a breeding population at White Island. A small group of seals could have travelled over the ice (Stirling 1972), swum under the ice from Erebus Bay, or followed a series of cracks that may have opened near Brown Peninsula and Black Island (Stirling 1966).

Live seals or seal sign (i.e., scat or tracks in the snow) have never been reported $>5 \mathrm{~km}$ from the southern edge of open water in Erebus Bay (Fig. 1) in over 50 years of constant human presence. Over-ice immigration is therefore an unlikely explanation for the founding of the White Island population.

Castellini et al. (1991) recorded a maximum dive duration of 82 min for Weddell seals diving from an isolated hole; and Davis et al. (2003) found a maximal swim speed of $3.1 \mathrm{~m} / \mathrm{sec}$ for a seal traveling on a long-distance dive. In both studies, the seals were swimming away from and returning to the only entrance-exit hole in the area. Combining these maximum values yields an estimated maximum under-ice swim distance of approximately $15.2 \mathrm{~km}$ for a Weddell seal. Even the maximum break-out documented in 1947 (see Fig. 1) would not have provided sufficient access for a seal to swim below the ice shelf to White Island without breathing, and the thickness of the ice shelf suggests that air pockets do not exist underneath the shelf.

However, the possible break-out of the ice shelf between 1947 and 1956, as speculated by Swithinbank (1970), would have reduced the distance by more than half and easily put the tidal crack along the northwest side of White Island within range from Erebus Bay (Fig. 1). A likely founding scenario is therefore that, while the break remained open, seals would have made foraging trips to White Island. At any time, a strong gale could have blown back the broken ice which, after re-freezing, would have trapped a minimum of five seals at White Island. The presence of an abundant food supply may have limited the tendency of seals visiting White Island to search elsewhere and reduced the need to escape to open water in the years before the northern edge of the ice shelf became re-established at a distance too great for under-ice transit.

The time window of 1947-1956 that is suggested for the break-out of the ice shelf is compatible with historical accounts, such as the lack of sightings during the Scott expeditions and a first record of seals at White Island in 1958. In addition, this timeframe is in line with evidence from our parentage and pedigree analysis that suggested that the founders occupied White Island around 1950-1957.

The scenario that animals present in 1950-1957 could have still been reproducing in the 1970s is plausible given 
the following evidence of longevity: at least eight seals (six females, two males) were seen during the study period to be carrying tags or remnants of tags put out between 1968 and 1978. Four of those (three females, one male) were seen in 2000, and two of the females pupped. Tag histories indicate that only four live pups were tagged in 1978. Therefore, those four individuals were a minimum of 22 in 2000, assuming perfect survival of the entire 1978 cohort. One female was still alive in 2005 (Kelly Proffitt, personal communication). It is unknown how long Weddell seals live but White Island likely represents an ideal situation. The isolation of the island prevents access by predators such as killer whales (Orcinus orca) and leopard seals (Hydrurga leptonyx); the productivity under the ice shelf and small population provides sufficient forage (Castellini et al. 1984) and the inability to emigrate likely reduces any overwinter energy expenditure. Cameron and Siniff (2004) found no evidence of senescence in Weddell seals up to age 17 and suggest that they live up to at least 27. Closely related crabeater seals (Lobodon carcinophagus) reportedly live to at least 39 years (Boveng 1993).

\section{Measures of $N_{\mathrm{e}} / N_{\mathrm{b}}$}

Our complete sampling of the population and the presence of first generation after founding allowed us to directly calculate values for the minimum number of founders and the number of breeders each year from 1990 to 1999. Comparable studies of founder or bottleneck events, however, often rely on incomplete sampling and models to estimate these values. Our data allowed us to compare direct versus indirect measures of $N_{\mathrm{b}}$ in the founding group and in subsequent generations (Table 4). We implemented two methods that use genotype data from a population sample to estimate the effective number of individuals that have generated that group, i.e., the effective number in the previous generation (Waples 2005). In the case of species with overlapping generations, these methods more accurately estimate the effective number of breeders $\left(N_{\mathrm{b}}\right)$ that produced the sample (Waples and Yokota 2007), a variable which should be directly comparable to our results based on breeding data.

Results compiled in Table 4 show that the approaches used are all congruent in inferring effective number of breeders making up generations $G_{0}$ (founders), $G_{1}$ and $G_{2}$. The method based on linkage equilibrium following Waples (2006) appeared to be slightly over-estimating the number of breeders, mostly in the founding generation; the discrepancy being less evident for the $G_{1}$ estimate and absent for $G_{2}$.

In addition, our results show that the simpler approach of using the loss of heterozygosity and the genetic drift formula (following Hedrick et al. 2001; see also Hedrick
2005) also provides a reliable estimate of the number of founders.

Current and future status of the population

Lack of competition and predation, and abundance of prey likely favored the establishment and early growth of the Weddell seal population at White Island. Between 1990 and 2000, the population appeared to have stabilized around 26 individuals. However, demographic characteristics of the population suggest that its long-term survival may be in doubt. High adult survivorship between 1990 and 2000 was the critical factor sustaining the White Island population, offsetting apparent low pup survival. Female reproductive success at White Island $(0.33 \sigma=0.06)$ was half the rate for females $>6$ years of age in the source population (Gelatt 2001) during the 1991-1998 period (mean $=0.64, \sigma=0.08, N=2,081, T$-test, $P<0.0001$ ). The minimum mortality rate of $10.4 \%$ for pups based on pups found dead on the ice exceeded the $5 \%$ noted in the Erebus Bay population (Stirling 1971c; Schreer et al. 1996). In addition, we found a strong bias in the sex ratio in both pup births and pup survivors (20m:45f and 1m:6f, respectively). In Erebus Bay, the sex ratio is around parity, with a slight excess towards males (Stirling 1971b; Cameron and Siniff 2004). A sex ratio skewed towards females has been related to difficult environmental conditions experienced by Weddell seals in McMurdo Sound (Hastings 1996) and reduced survivorship of male pups has been linked to the mother's condition (Hastings and Testa 1998; Hastings et al. 1999). Sex ratio distortion may also be associated with inbreeding depression (Senner 1980; but see Frankham and Wilcken 2006). Current $N_{\mathrm{e}}$ is certainly below the values deemed necessary for population shortterm persistence and longer term maintenance of genetic variation and adaptive potential (Franklin 1980; Franklin and Frankham 1998). Lastly, the impossibility of migration (Stirling 1966) renders the population highly vulnerable to inbreeding and stochastic effects.

Low effective number, skewed sex ratio and the observation of congenital malformations (Testa and Scotton 1999) suggest inbreeding depression. By comparing the White Island population to that of Erebus Bay, we found an effective inbreeding coefficient $\left(F_{\mathrm{e}}\right)$ of 0.29 . Our pedigree analysis highlighted seven inbred mating events. That number, if our founding model is correct, reaches 57/66. Indeed, given the composition and the relative success of the founding group (see Fig. 2), any pups initially recruited into the population would have included half and fullsiblings. Moreover, our analysis suggests that individual inbreeding coefficient is correlated to pup survival. Of the seven pups known to have survived since 1990, six were females, all were fathered by one of two males, and there 
were two cases of full siblings. Thus, any future recruitment will be highly inbred and the White Island population will become increasingly vulnerable to extinction due to loss of genetic diversity and adaptive potential (Allendorf and Leary 1986; Frankham 1997).

The Weddell seal population at White Island is a natural example of a situation representative of the small isolated populations of mammals continually created by habitat loss and other anthropogenic factors. Based on our results, we may predict that the population will likely decrease and face inbreeding depression, placing it at a high risk of extinction. There is indeed evidence that pup births have decreased to an average of $<3$ pups/year 2001-2007 (Kelly Proffitt, personal communication). Ongoing monitoring of this population will provide a unique opportunity to verify our predictions and further observe the effects of genetic, environmental and demographic forces acting on small isolated populations.

Acknowledgments Many persons graciously supplied samples, contacts, personal accounts, letters, field notes or pertinent reports, including J. Basset, M. Castellini, M. Crawley, A. DeVries, R. Eisert, L. Fuiman, R. Gee, B. Karl, H. Keys, G. Knox, G. Kooyman, L. Rea, C. Swithinbank, J. W. Testa and P. Wilson. Samples AF31, AF32, AF37 and AF0875 were provided by the University of Alaska museum, frozen tissue collection (J. A. Cook and G. H. Jarrell). We especially thank G. Knox for donating his field journals. M. Castellini, W. Testa and students, University of Alaska, Fairbanks, tagged seals and collected data at White Island, 1990-1994. K. Abernathy, A. Brunet, M. Cameron, C. Counard, S. Dahl, J. Degroot, R. Jensen, R. Johnson, D. McNulty, S. Melin, D. Monson, R. Reichle, B. Stewart and P. Yochem assisted with fieldwork during 1995-1999. R. Garrott, K. Proffitt and students at Montana State University provided recent population data collected since 2000. We thank D. Ainley, B. Dickerson, G. Duke, H. Huber, W. Testa, and two anonymous reviewers for manuscript reviews. Laboratory analyses were performed at the University of Alberta. Logistical support was provided by USAP. All sampling was carried out under US Marine Mammal Permit No. 976 and University of Minnesota Animal Care guidelines. This research was funded by National Science Foundation grants OPP-9420818 and OPP-9725820.

\section{References}

Allendorf FW, Leary RF (1986) Heterozygosity and fitness in natural populations of animals. In: Soulé ME (ed) Conservation biology: the science of scarcity and diversity. Sinauer, Sunderland, pp 57-76

Armitage AB (1905) Two years in the Antarctic: being a narrative of the British National Antarctic Expedition. Edward Arnold Ltd., London

Boveng PL (1993) Variability in crabeater seal population and the marine ecosystem near the Antarctic Peninsula. Ph.D. Dissertation, Montana State University

Bowcock AM, Ruiz-Linares A, Tomfohrde J et al (1994) High resolution of human evolutionary trees with polymorphic microsatellites. Nature 368(6470):455-457. doi:10.1038/368455a0

Cameron MF, Siniff DB (2004) Age-specific survival, abundance, and immigration rates of a Weddell seal (Leptonychotes weddellii) population in McMurdo Sound, Antarctica. Can J Zool 82(4):601-615. doi:10.1139/z04-025
Carmichael LE, Clark W, Strobeck C (2000) Development and characterization of microsatellite loci from lynx (Lynx canadensis), and their use in other felids. Mol Ecol 9(12):2197-2198. doi:10.1046/j.1365-294X.2000.105323.x

Caro TM, Laurenson MK (1994) Ecological and genetic factors in conservation-a cautionary tale. Science 263(5146):485-486. doi: $10.1126 /$ science. 8290956

Castellini MA, Davis RW, Davis M, Horning M (1984) Antarctic marine life under the McMurdo ice shelf at White Island-a link between nutrient influx and seal population. Polar Biol 2(4):229_ 231. doi:10.1007/BF00263629

Castellini MA, Davis RW, Kooyman GL (1991) Annual cycles of diving behavior and ecology of the Weddell seal. University of California Press, Berkeley

Caughley G (1959) Observations on the seals of Ross Island during the 1958-1959 summer. Dominion Museum, Wellington

Caughley G (1994) Directions in conservation biology. J Anim Ecol 63(2):215-244. doi: $10.2307 / 5542$

Coltman DW, Bowen WD, Wright JM (1996) PCR primers for harbour seal (phoca vitulina concolour) microsatellites amplify polymorphic loci in other pinniped species. Mol Ecol 5(1):161163. doi:10.1111/j.1365-294X.1996.tb00303.x

Creel S (1998) Social organization and effective population size in carnivores. In: Caro TM (ed) Behavioral ecology and conservation biology. Oxford University Press, New York, pp 246-265

Davis CS, Strobeck C (1998) Isolation, variability, and cross-species amplification of polymorphic microsatellite loci in the family Mustelidae. Mol Ecol 7(12):1776-1778

Davis CS, Gelatt TS, Siniff D, Strobeck A (2002) Dinucleotide microsatellite markers from the Antarctic seals and their use in other Pinnipeds. Mol Ecol Notes 2(3):203-208. doi:10.1046/ j.1471-8286.2002.00187.x

Davis RW, Fuiman LA, Williams TM et al (2003) Classification of Weddell seal dives based on 3-dimensional movements and video-recorded observations. Mar Ecol Prog Ser 264:109-122. doi:10.3354/meps264109

Davis CS, Stirling I, Strobeck C, Coltman DW (2008) Population structure of ice-breeding seals. Mol Ecol 17:3078-3094. doi: 10.1111/j.1365-294X.2008.03819.x

Eldridge MDB, King JM, Loupis AK et al (1999) Unprecedented low levels of genetic variation and inbreeding depression in an island population of the black-footed rock-wallaby. Conserv Biol 13(3):531-541. doi:10.1046/j.1523-1739.1999.98115.x

Felsenstein J (1993) PHYLIP (phylogeny inference package) Version 3.572. Distributed by the author. Department of Genome Sciences, University of Washington, Seattle

Frankham R (1997) Do island populations have less genetic variation than mainland populations? Heredity 78:311-327. doi:10.1038/ hdy. 1997.46

Frankham R (1998) Inbreeding and extinction: Island populations. Conserv Biol 12(3):665-675. doi:10.1046/j.1523-1739.1998. 96456.x

Frankham R, Wilcken J (2006) Does inbreeding distort sex-ratios? Conserv Genet 7(6):879-893. doi:10.1007/s10592-006-9129-6

Franklin IR (1980) Evolutionary change in small populations. In: Soulé ME, Wilcox BA (eds) Conservation biology: an evolutionary-ecological perspective. Sinauer, Sunderland, pp 135-149

Franklin IR, Frankham R (1998) How large must populations be to retain evolutionary potential? Anim Conserv 1(1):69-70. doi: 10.1111/j.1469-1795.1998.tb00228.x

Garbe JR, Da Y (2006) Pedigraph ${ }^{\mathrm{TM}}$ Version 2.3. Department of Animal Science, University of Minnesota, Minneapolis

Gelatt TS (2001) Male reproductive success, relatedness, and the mating system of Weddell seals in McMurdo Sound, Antarctica. Ph.D. Dissertation, University of Minnesota 
Gelatt TS, Davis CS, Siniff DB, Strobeck C (2001) Molecular evidence for twinning in Weddell seals (Leptonychotes weddellii). J Mammal 82(2):491-499. doi:10.1644/1545-1542(2001) 082<0491:MEFTIW>2.0.CO;2

Gemmell NJ, Allen PJ, Goodman SJ, Reed JZ (1997) Interspecific microsatellite markers for the study of pinniped populations. Mol Ecol 6(7):661-666. doi:10.1046/j.1365-294X.1997.00235.x

Gilpin M, Soulé ME (1986) Minimum viable populations: processes of species extinctions. In: Soulé ME (ed) Conservation biology: the science of scarcity and diversity. Sinauer, Sunderland, pp 19-34

Hadley GL, Rotella JJ, Garrott RA, Nichols JD (2006) Variation in probability of first reproduction of Weddell seals. J Anim Ecol 75(5):1058-1070. doi:10.1111/j.1365-2656.2006.01118.x

Hastings KK (1996) Juvenile survival and maternal strategies of Weddell seals in McMurdo Sound, Antarctica. M.Sc. Dissertation, University of Alaska

Hastings KK, Testa JW (1998) Maternal and birth colony effects on survival of Weddell seal offspring from McMurdo Sound, Antarctica. J Anim Ecol 67(5):722-740. doi:10.1046/j.1365-2656. 1998.00242.x

Hastings KK, Testa JW, Rexstad EA (1999) Interannual variation in survival of juvenile Weddell seals (Leptonychotes weddellii) from McMurdo Sound, Antarctica: effects of cohort, sex and age. J Zool (Lond) 248:307-323. doi:10.1111/j.1469-7998. 1999.tb01031.x

Hedrick PW (1996) Conservation genetics and molecular techniques: a perspective. In: Smith RB, Wayne RK (eds) Molecular genetic approaches in conservation. Oxford University Press, New York, pp 459-477

Hedrick PW (2005) Genetics of populations, 3rd edn. Jones and Bartlett, Sudbury

Hedrick PW, Lacy RC, Allendorf FW, Soule ME (1996) Directions in conservation biology: comments on caughley. Conserv Biol 10(5):1312-1320. doi:10.1046/j.1523-1739.1996.10051312.x

Hedrick PW, Gutierrez-Espeleta GA, Lee RN (2001) Founder effect in an island population of bighorn sheep. Mol Ecol 10(4):851857. doi:10.1046/j.1365-294X.2001.01243.x

Heine AJ (1960) Seals at White Island, Antarctica. Antarctic 2:272273

Heine AJ (1963) Ice breakout around the southern end of Ross Island, Antarctica. NZ J Geol Geophys 6:395-401

Kalinowski ST, Taper ML, Marshall TC (2007) Revising how the computer program cervus accommodates genotyping error increases success in paternity assignment. Mol Ecol 16(5): 1099-1106. doi:10.1111/j.1365-294X.2007.03089.x

Kluge AG, Farris JS (1969) Quantitative phyletics and the evolution of anurans. Syst Zool 18(1):1-32. doi:10.2307/2412407

Lacy RC, Ballou JD, Princee F (1995) Pedigree analysis for population management. In: Ballou JD, Gilpin M, Foose TJ et al (eds) Population management for survival and recovery. Columbia University Press, New York, pp 57-75

Lande R, Barrowclough GF (1987) Effective population size, genetic variation, and their use in population management. In: Soulé ME (ed) Viable populations for conservation. Cambridge University Press, Cambridge, pp 87-123

MacDonald WJP, Hatherton T (1961) Movement of the Ross Ice Shelf near scott base. J Glaciol 3(29):859-866

Marshall TC, Slate J, Kruuk LEB, Pemberton JM (1998) Statistical confidence for likelihood-based paternity inference in natural populations. Mol Ecol 7(5):639-655. doi:10.1046/j.1365-294x. 1998.00374.x

May RM (1995) The cheetah controversy. Nature 374(6520):309310. doi: $10.1038 / 374309 \mathrm{a} 0$

Menotti-Raymond M, O’Brien SJ (1995) Hypervariable genomic variation to reconstruct the natural history of populations- lessons from the big cats. Electrophoresis 16(9):1771-1774. doi: 10.1002/elps.11501601293

Nei M, Roychouddhoury AK (1974) Sampling variances of heterozygosity and genetic distance. Genetics 76(2):379-390

Nunney L, Campbell KA (1993) Assessing minimum viable population size-demography meets population genetics. Trends Ecol Evol 8(7):234-239. doi:10.1016/0169-5347(93)90197-W

Ostrander EA, Sprague GF, Rine J (1993) Identification and characterization of dinucleotide repeat $(\mathrm{CA})_{n}$ markers for genetic mapping in dog. Genomics 16(1):207-213. doi:10.1006/geno. 1993.1160

Packer C, Pusey AE, Rowley H et al (1991) Case study of a population bottleneck-lions of the ngorongoro crater. Conserv Biol 5(2):219-230. doi:10.1111/j.1523-1739.1991.tb00127.x

Paetkau D, Strobeck C (1995) The molecular basis and evolutionary history of a microsatellite null allele in bears. Mol Ecol 4:519520. doi:10.1111/j.1365-294X.1995.tb00248.x

Peel D, Ovenden JR, Peel SL (2004) NeEstimator: software for estimating effective population size Version 1.3. Department of Primary Industries and Fisheries, Queensland Government, Queensland

Prebble MM (1967) Ice breakout, McMurdo Sound, Antarctica. NZ J Geol Geophys 11:908-921

Proffitt KM, Garrott RA, Rotella JJ, Wheatley KE (2007) Environmental and senescent related variations in Weddell seal body mass: implications for age-specific reproductive performance. Oikos 116:1683-1690. doi:10.1111/j.0030-1299. 2007.16139.x

Pudovkin AI, Zaykin DV, Hedgecock D (1996) On the potential for estimating the effective number of breeders from heterozygoteexcess in progeny. Genetics 144(1):383-387

Raymond M, Rousset F (1995) GENEPOP (version 1.2): population Genetics Software for exact tests and ecumenicism. J Hered 86(3):248-249

Riedman M (1990) The pinnipeds: seals, sea lions, and walruses. University of California Press, Berkeley

Schreer JF, Hastings KK, Testa JW (1996) Preweaning mortality of Weddell seal pups. Can J Zool 74(9):1775-1778. doi:10.1139/ z96-195

Seaver G (1933) Edward Wilson of the Antarctic: naturalist and friend: together with a memoir of Oriana Wilson. John Murray, London

Senner J (1980) Inbreeding depression and survival of zoo populations. In: Soulé ME, Wilcox BA (eds) Conservation biology: an evolutionary-ecological perspective. Sinauer Associates, Sunderland, pp 209-224

Shaughnessy PD (1969) Transferrin polymorphism and population structure of Weddell seal Leptonychotes weddelli (Lesson). Aust J Biol Sci 22(6):1581-1584

Shields GF, Kocher TD (1991) Phylogenetic relationships of North American ursids based on analysis of mitochondrial DNA. Evol Int J Org Evol 45(1):218-221. doi:10.2307/2409495

Siniff DB, Demaster DP, Hofman RJ, Eberhardt LL (1977) Analysis of dynamics of a Weddell seal population. Ecol Monogr 47(3):319-335. doi:10.2307/1942520

Stewart BS, Yochem PK, Gelatt TS, Siniff DB (2000) Dispersion and habitat use of Weddell seals (Leptonychotes weddelli) in the Ross Sea, Antarctica, during their first year of life. In: Davison WC, Howard-Williams C, Broady P (eds) Antarctic ecosystems: models for wider ecological understanding. Caxton Press, Christchurch, New Zealand, pp 71-76

Stirling I (1966) The seals at White Island: a hypothesis on their origin. Antarctic 4:310-313

Stirling I (1969) Ecology of Weddell Seal in McMurdo Sound, Antarctica. Ecology 50(4):573-586. doi:10.2307/1936247 
Stirling I (1971a) Leptonychotes weddelli. Mamm Species 6:1-5. doi: $10.2307 / 3503841$

Stirling I (1971b) Variation in sex ratio of newborn Weddell seals during pupping season. J Mammal 52(4):842-844. doi:10.2307/ 1378943

Stirling I (1971c) Population dynamics of the Weddell seal (Leptonychotes weddelli) in McMurdo Sound, Antarctica, 1966-1968. In: Burt WH (ed) Antarctic pinnipedia. Antarctic research series, vol 18. American Geophysical Union, Washington, pp 141-161

Stirling I (1972) Regulation of numbers of an apparently isolated population of Weddell seals (Leptonychotes weddelli). J Mammal 53(1):107-115. doi:10.2307/1378831

Stuart AW, Bull C (1963) Glaciological observations on the Ross Ice Shelf near scott base, Antarctica. J Glaciol 4(34):399-414

Swithinbank C (1970) Ice movement in the McMurdo Sound area of Antarctica. In: Gow AJ et al. (eds) Proceedings of the international symposium on Antarctic glaciological exploration, Hanover, New Hampshire 3-7 September 1968. International Association of Scientific Hydrology

Testa JW (1994) Over-winter movements and diving behavior of female Weddell seals (Leptonychotes weddellii) in the Southwestern Ross Sea, Antarctica. Can J Zool 72(10):1700-1710. doi:10.1139/z94-229

Testa JW, Scotton BD (1999) Dynamics of an isolated population of Weddell seals (Leptonychotes weddellii) at White Island, Antarctica. J Mammal 80(1):82-90. doi:10.2307/1383210
Testa JW, Siniff DB (1987) Population dynamics of Weddell seals (Leptonychotes weddelli) in McMurdo Sound, Antarctica. Ecol Monogr 57(2):149-165. doi:10.2307/1942622

Waples RS (2005) Genetic estimates of contemporary effective population size: to what time periods do the estimates apply? Mol Ecol 14(11):3335-3352. doi:10.1111/j.1365-294X.2005. 02673.x

Waples RS (2006) A bias correction for estimates of effective population size based on linkage disequilibrium at unlinked gene loci. Conserv Genet 7(2):167-184. doi:10.1007/s10592-0059100-y

Waples RS, Do C (2008) LDNE: a program for estimating effective population size from data on linkage disequilibrium. Mol Ecol Res 8(4):753-756. doi:10.1111/j.1755-0998.2007.02061.x

Waples RS, Yokota M (2007) Temporal estimates of effective population size in species with overlapping generations. Genetics 175(1):219-233. doi:10.1534/genetics.106.065300

Wilson EA (1907) Pinnipedia. In: Natural history. British National Antarctic Expedition 1901-04, vol 2. British Museum, London, pp 1-66

Worsley FA (1931) Endurance: an epic of polar adventure. W.W. Norton, New York 